\title{
Outcomes with fracture-level transpedicular screws used for thoracolumbar junction fractures
}

\author{
S.V. Likhachev, V.V. Zaretskov, V.B. Arsenievich, V.V. Ostrovskij, A.E. Shulga, A.V. Zaretskov
}

Saratov State Medical University named after V.I. Razumovsky, Saratov, Russian Federation

\begin{abstract}
Background Short-segment transpedicular screw fixation (SSTSF) is the preferred treatment option for thoracolumbar burst fractures. Adding screws in the fractured body may be helpful in achieving and maintaining fracture reduction. However, the operative approach is disputed. Objective To compare clinical outcomes of transpedicular fixation with and without screws in the fractured vertebral body after isolated uncomplicated fractures at the thoracolumbar junction. Material and methods A retrospective cohort study enrolled 62 patients with Th11-L2 thoracolumbar burst fractures (AOSpine A3, A4) who underwent SSTSF with $(\mathrm{n}=32)$ and without $(\mathrm{n}=30)$ pedicle screws at the fracture level. Demographic data of the patients, operating time and blood loss were registered. Clinical evaluation using Visual analogue scale (VAS ) for pain, Oswestry Disability Index (ODI) to quantify disability and imaging parameters of segmental kyphosis, loss of correction, anterior vertebral body height (AVBH) at the fracture level, spinal canal stenosis (SCS) were measured preoperatively, at one week, 1 month, 6 and 12 months postoperatively. Results The patients of the two groups showed no statistically significant differences in the demographic data, VAS and ODI scores, measurements of kyphotic angle, AVBH, SCS preoperatively $(p>0.05)$. Screws at the fracture level did not affect the operating time and intraoperative blood loss relative to conventional no-screw group. Benefits with fracture screws were evident at 7 days $(p<0.01)$ measuring SCS, at 6 months $(p<0.01)$ and $12(\mathrm{p}<0.01)$ months measuring kyphotic angle. There was better kyphosis correction $(\mathrm{p}<0.01)$ and AVBH $(\mathrm{p}=0.034)$ seen at 12 months after surgery. Conclusion Reinforcement of a broken vertebra with fracture-level screws has been shown to provide better stability of clinical and radiographic results as compared to those with conventional SSTSF.

Keywords: thoracolumbar junction, burst fracture, transpedicular fixation, fracture-level transpedicular screws
\end{abstract}

\section{INTRODUCTION}

Fractures of the thoracolumbar junction (T11-L2), the transition from the less mobile thoracic spine to the more dynamic lumbar spine, are the most common fractures of the spinal column. Thoracolumbar burst fractures (AOSpine A3, A4) are normally stabilized with surgical techniques. Common surgical goals are to obtain the most stable fixation, correct the deformity and prevent the recurrence, produce spinal decompression to allow early ambulation. Shortsegment transpedicular screw fixation (SSTSF) is the preferred treatment option for thoracolumbar burst fractures for stabilizing the three-column spine. The technique is characterized by a relatively simple performance, less surgical trauma and decreased blood loss. Polysegmental fixation, circular stabilization of the spine and procedures performed using the anterior approach are alternatives to the conventional transpedicular screw fixation. Disadvantages reported with SSTSF include unstable metal construct, loss of correction at a long term, recurrence of spinal stenosis, neurologic deficit and pain. Short-segment instrumentation can be augmented with additional pedicle screws placed at the fracture level. The intermediate screws inside the fractured vertebra can improve stability of the anterior column due to additional reinforcement and reduce stress on each pedicle screw. Decision on intermediate screws to be placed at fracture level is made by the surgeon.

Objective To compare clinical outcomes of transpedicular fixation with and without additional screws in the fractured vertebral body after isolated uncomplicated fractures at the thoracolumbar junction.

\section{MATERIAL AND METHODS}

A retrospective cohort study enrolled 78 patients with Th11-L2 thoracolumbar burst fractures who underwent surgical treatment at the institute between January 2016 and December 2018. Inclusion criteria were an isolated uncomplicated fracture at the thoracolumbar junction (AOSpine A3N0M1, A4N0M1) [14], SSTSF, follow-up period of at least one year. Exclusion criteria were circular stabilization

[D Likhachev S.V., Zaretskov V.V., Arsenievich V.B., Ostrovskij V.V., Shulga A.E., Zaretskov A.V. Outcomes with fracturelevel transpedicular screws used for thoracolumbar junction fractures. Genij Ortopedii, 2020, vol. 26, no 4, pp. $548-554$. DOI 10.18019/1028-4427-2020-26-4-548-554 
of the spine, polysegmental transpedicular systems, neurologic deficit, postoperative infection, osteoporosis. A total of 62 patients met the inclusion and exclusion criteria and were allocated to two groups depending on the type of surgery performed. Patients of group I $(n=30)$ underwent bilateral transpedicular four-screw fixation. Patients of group II $(n=32)$ underwent similar procedure with two screws added in the fracture body. Clinical evaluation and imaging parameters were measured preoperatively, at one week, 1, 6 and 12 months postoperatively. General characteristics of the patients are presented in Table 1.

Surgical technique Surgeries were performed with use of general anesthesia (ALV + TIVA). Patients were in supine position with cushions placed under the thoracic cage and pelvis. The standard median approach provided exposure to the posterior vertebral structures and the adjacent vertebrae. Bilateral transpedicular four-screw fixation was performed for the patients of both groups with two screws added at fracture level in group II. The screws were connected by rods, distraction was provided for remodeling of the broken vertebra and the assembly accomplished.
$6.5 \mathrm{~mm}$ screws 40 or $45 \mathrm{~mm}$ long were employed for the cases. For the construct, $5.5 \mathrm{~mm}$ pins were used. Implants from one manufacturer were used for the cases, and surgeries were performed by the same surgical team.

Clinical and imaging measurements Patients were requested to fill out questionnaires to evaluate pain intensity with 10-point Visual analogue scale (VAS-10) and with Oswestry Disability Index (ODI) for low back pain to quantify disability preoperatively, at one week, 1, 6 and 12 months postoperatively. Preoperative and postoperative radiographs were used to assess positioning of the intermediate pedicle screws and measure kyphotic angle by Cobb method. Kyphosis was evaluated by measuring anterior vertebral body height $(\mathrm{AVBH}$, $\mathrm{mm}$ ) at the fracture level. Linear and angulation measurements were produced using Surgimap (Spine Software, version 2.2.15.1). Axial CT scans were used to measure spinal canal stenosis (SCS, \%) at the level of maximal retropulsion of bone fragments and assess decompression at 7 days postsurgery.

Table 1

General characteristics of patients

\begin{tabular}{|c|c|c|c|c|c|}
\hline \multirow{3}{*}{\multicolumn{2}{|c|}{ Characteristic }} & \multicolumn{4}{|c|}{ Type of surgery } \\
\hline & & \multicolumn{2}{|c|}{ Standard SSTSF } & \multicolumn{2}{|c|}{$\begin{array}{c}\text { SSTSF with intermediate screws placed } \\
\text { at fracture level }\end{array}$} \\
\hline & & $\mathrm{N}$ & $\%$ & $\mathrm{~N}$ & $\%$ \\
\hline \multicolumn{6}{|l|}{ Sex } \\
\hline male & \multirow{3}{*}{ valid } & 21 & 70.0 & 22 & 68.8 \\
\hline female & & 9 & 30.0 & 10 & 31.3 \\
\hline Total & & 30 & 100.0 & 32 & 100.0 \\
\hline \multicolumn{6}{|l|}{ Fracture level } \\
\hline Th11 & \multirow{5}{*}{ valid } & 3 & 10.0 & 3 & 9.4 \\
\hline Th12 & & 7 & 23.3 & 9 & 28.1 \\
\hline L1 & & 15 & 50.0 & 14 & 43.8 \\
\hline L2 & & 5 & 16.7 & 6 & 18.8 \\
\hline Total & & 30 & 100.0 & 32 & 100.0 \\
\hline \multicolumn{6}{|l|}{ Fracture pattern } \\
\hline A3 & \multirow{3}{*}{ valid } & 20 & 66.7 & 21 & 65.6 \\
\hline A4 & & 10 & 33.3 & 11 & 34.4 \\
\hline Total & & 30 & 100.0 & 32 & 100.0 \\
\hline \multicolumn{6}{|l|}{ Age } \\
\hline \multirow{3}{*}{ percentile } & 25 & \multicolumn{2}{|c|}{25.0000} & \multicolumn{2}{|c|}{25.0000} \\
\hline & 50 & \multicolumn{2}{|c|}{31.5000} & \multicolumn{2}{|c|}{29.0000} \\
\hline & 75 & \multicolumn{2}{|c|}{43.0000} & \multicolumn{2}{|c|}{46.7500} \\
\hline \multicolumn{6}{|l|}{ Body weight, kg } \\
\hline \multirow{3}{*}{ percentile } & 25 & \multicolumn{2}{|c|}{62.750} & \multicolumn{2}{|c|}{64.000} \\
\hline & 50 & \multicolumn{2}{|c|}{71.000} & \multicolumn{2}{|c|}{72.000} \\
\hline & 75 & \multicolumn{2}{|c|}{80.750} & \multicolumn{2}{|c|}{79.750} \\
\hline
\end{tabular}


Statistical analysis Statistical data analysis was performed using Microsoft Excel 13 and Statistica for Windows - 6.0 computer program. Non-parametric statistical tests (Wilcoxon) was used when distribution was different from the norm. The KolmogorovSmirnov and Shapiro-Wilk tests were employed to determine normality of distribution in the groups. Most of the variables were not normally distributed, and the median, $25^{\text {th }}$ and $75^{\text {th }}$ percentiles were used for description. Non-parametric two-sample Mann-
Whitney $U$ test and the Newman-Keuls method were used to compare differences between two independent groups. Pearson's chi-squared and twotailed Fisher's exact test with observations less than 5 in a table cell were applied to identify differences in scores evaluating outcomes between the groups. The Wilcoxon signed-rank test was used to analyze kyphotic angles at different follow-up periods. For calculations, a significance level of $<0.05$ was adopted.

\section{RESULTS}

Median age in group I was 31.5 (range, 2543) years with male/female ratio of 21:9. Median age in group II was 29.0 (range, 25-46.7) years with male/female ratio of 22:10 (Table 1). No statistically significant differences in age and sex were observed in groups I and II ( $p=0.782$ and $p=0.915$, respectively). Mean body weight was 71 (range, 62.7-80.7) kg and 72 (range, 64-79.7) kg in groups I and II, respectively. There were no statistically significant differences in body weight between the groups $(p=0.832)$. Vertebral fractures were distributed in groups I/II as follows, Th11: 3/3, Th12: 7/9, L1: 15/14, L2: 5/6. Fracture patterns in groups I/II were A3: 20/21, A4 10/11. The groups appeared to be comparable by fracture level and morphology $(p=0.311$ and $p=0.931$, respectively). Patients of both groups underwent surgery at 7 (range, 4-8) days on average. Injuries in groups I/II resulted from a fall from height $12 / 11$ and RTA $18 / 21$. There were no statistically significant differences in operating time in the groups with the mean of 60 (range, 50 70) minutes. Mean intraoperative blood loss was comparable in both groups measuring 150 (range, 100-170) $\mathrm{mL}$. No early postoperative complcations were recorded. Mean length of hospitalization was 6 (range, 5-7) days in both groups.

Mean preoperative pain scored 7 (range, 7-8) on VAS scale. Antalgic effect was recorded postoperatively at all stages of questionnaire completion. No changes in pain dynamics were observed at 7 days, 1 and 12 months postsurgery. There were statistically significant differences in pain intensity noted at 6 months in the groups with mean VAS score of 2 (range, 2-3) in group I and 1 (range, 1-2) in group II $(\mathrm{p}=0.043)$. Quality of life improved progressively on ODI scale in both groups with considerable differences in support of group II recorded at 6 and 12 months postoperatively $(\mathrm{p}<0.01)$. Dynamics in VAS and ODI scores is presented in Figures 1 and 2.
Imaging parameters showed benefits of SSTST with intermediate pedicle screws added to fracture level. Preoperative segmental kyphosis demonstrated no significant differences between the groups $(\mathrm{p}=0.881)$ and measured $14.5^{\circ}$ (range, $12^{\circ}-19^{\circ}$ ) in group I and $15^{\circ}$ (range, $12^{\circ}-19^{\circ}$ ) in group II and was successfully corrected in both groups with the mean $5^{0}$ (range, $3^{0}-5^{0}$ ) in groups I and II at 7 days postsurgery. The correction was shown to equally decrease in both groups $(\mathrm{p}=0.698)$ during the first postoperative month and kyphotic angle measured $5^{\circ}$ (range, $4^{0}-5^{\circ}$ ) and $5^{0}$ (range, $3^{0}-6^{0}$ ) in groups I and II, respectively. Loss of correction was more evident in standard SSTSF group at 6 and 12 months. Mean segmental kyphosis measured $8^{\circ}$ (range, $6^{0}-10^{\circ}$ ) on average, with loss of correction of $3.5^{\circ}$ (range, $\left.1^{0}-6^{0}\right)$ in group I against mean kyphotic angle of $5^{0}\left(\right.$ range, $\left.5^{0}-6^{0}\right)$ with loss of correction of $1^{0}$ (range, $\left.0^{\circ}-2^{0}\right)$ in group II $(\mathrm{p}<0.01)$ at 12 -month follow-up. Dynamics in measurements of kyphosis and loss of correction is presented in Figures 3 and 4.

Although there were no statistically significant differences in mean AVBH measuring 19 (range, $14.7-21) \mathrm{mm}$ in group I and 19 (range, 14.221) $\mathrm{mm}$ in group II preoperatively and showing similar values at 7 days of surgical correction in both groups: 27 (range, 24-29) $\mathrm{mm}$ in group I and 27 (range, 23-30) mm in group II, AVBH was shown to decrease progressively in group I with statistically significant differences between the groups $(\mathrm{p}=0.034)$ measuring 24 (range, 20-26) $\mathrm{mm}$ in group I and 27 (range, 22-29.5) $\mathrm{mm}$ in group II. SSTSF with intermediate screws placed at fracture level appeared to maintain the AVBH better as compared to standard procedure (Fig. 5). Statistically significant advantages of indirect decompression of the spinal canal (Fig. 6) were seen with the use of SSTSF added 
with intermediate screws. Mean SCS measured 37 (range, 29.5-43.2) \% and 34.5 (range, 20.5-42) \% preoperatively in groups I and II, respectively. SCS

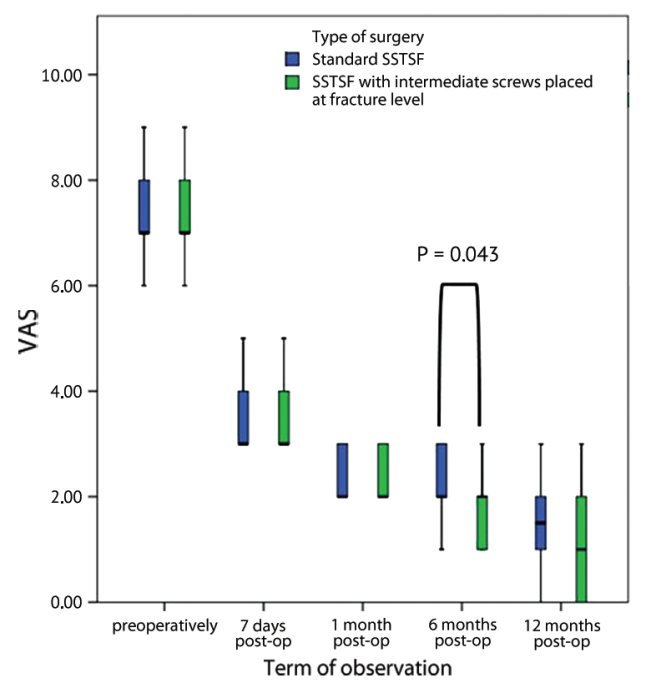

Fig. 1 Dynamics in scores of vertebrogenic pain syndrome

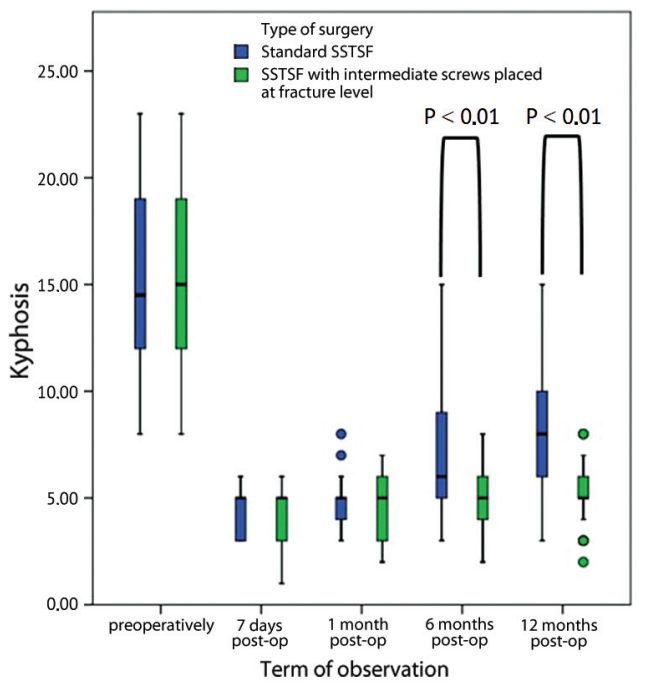

Fig. 3 Dynamics in measurements of segmental kyphosis

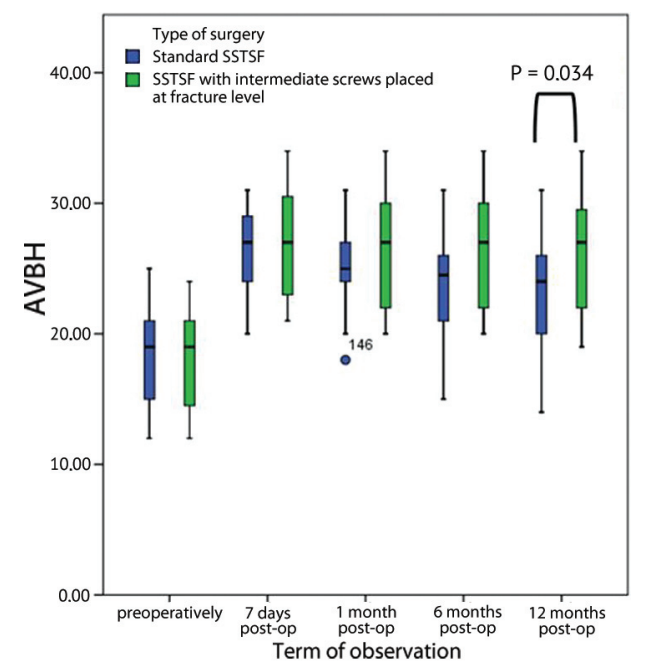

Fig. 5 Dynamics in measurements of the anterior vertebral body height improved to 15 (range, 8-20) \% with SSTSF and fracture level screws against 20 (range, 15-30) \% with use of SSTSF at 7-day follow-up $(\mathrm{p}<0.01)$.

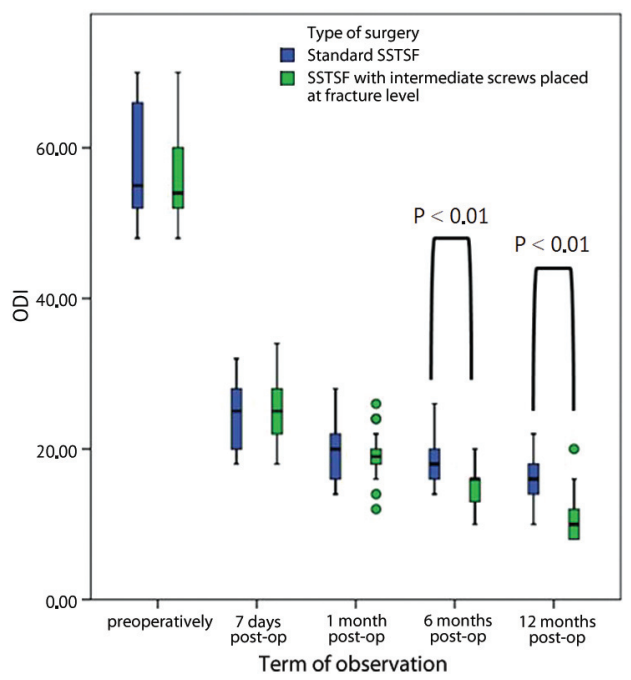

Fig. 2 Dynamics in scores of health-related quality of life

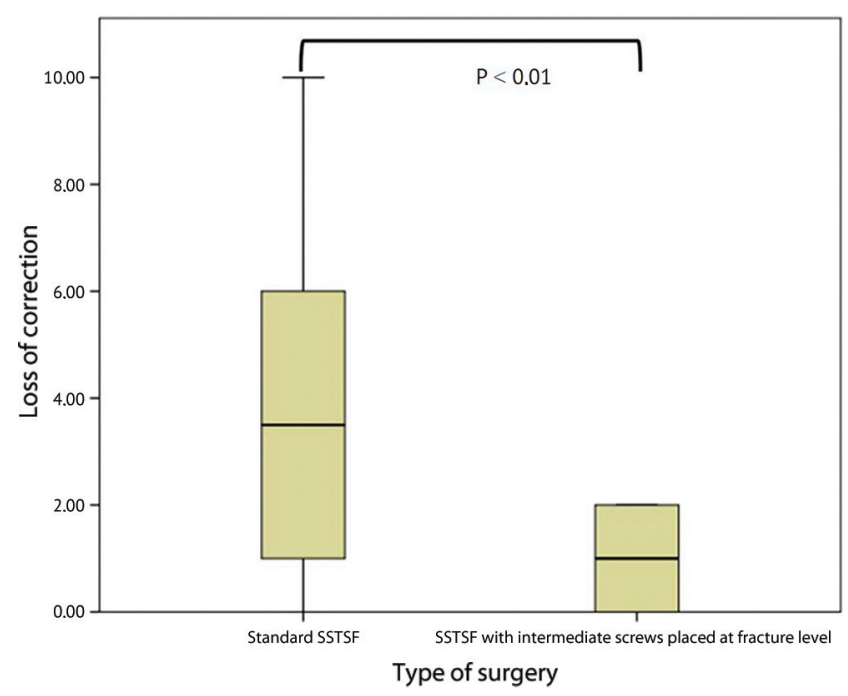

Fig. 4 Loss of correction at 12-month follow-up

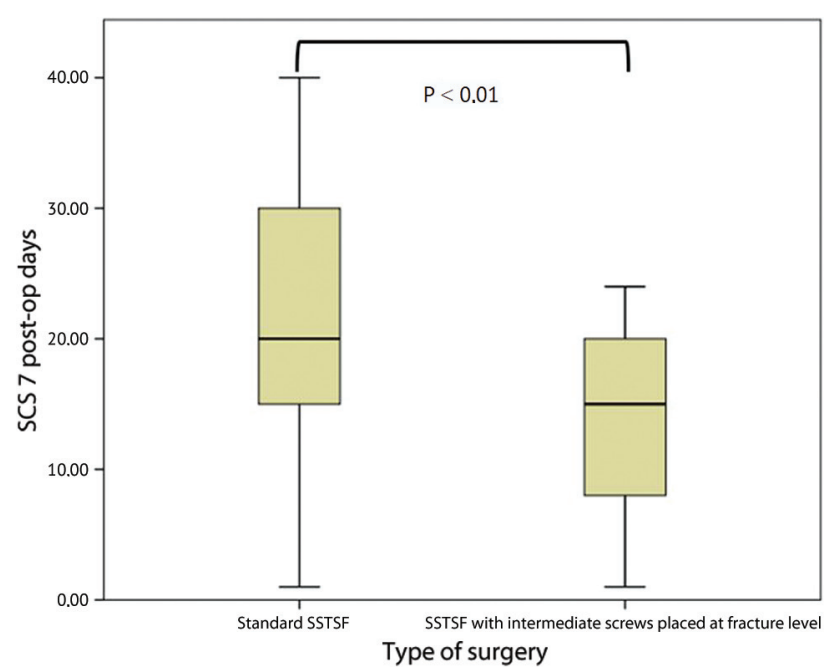

Fig. 6 Results of spinal decompression 


\section{DISCUSSION}

The best surgical approach and treatment of thoracolumbar burst fractures are still controversial due to the limited number of published comparative studies. There is lack of clear evidence-based consensus about the modalities of surgical management for these thoracolumbar fractures. Short-segment transpedicular screw fixation is the preferred treatment option for thoracolumbar burst fractures due to relatively low complication rate and simple performance [15-20]. However, several authors report a high rate of fixation failure or instrumentation migration to be associated with SSTSF [19, 21, 22]. Radiological signs of hardware failure are not always accompanied by clinical symptoms. SSTSF can be reinforced with additional intermediate pedicle screws placed bilaterally into the involved vertebra [23-25] and is seen as a feasible treatment strategy for thoracolumbar fractures [26]. The technique is superior to conventional SSTSF in stability due to the greater number of supporting components and additional reinforcement provided for the anterior spinal column avoiding negative effect on the spinal biomechanics relative to polysegmental fixation. There are few reports on the use of the technology in the Russian literature [27, 28]. There are few studies exploring radiological and clinical outcomes with application of intermediate pedicle screws in the available literature [29]. More long-term follow-up studies are needed.
There were no statistically significant differences in demographic data of both groups in our series. There were also no statistically significant differences in blood loss, operating time, preoperative and postoperative VAS and ODI scores. Imaging parameters measured with preoperative radiographs and films taken at one week and one month postoperatively were comparable in both groups. There were statistically significant differences in segmental kyphosis, AVBH and SCS observed at 6 and 12 months postoperatively. Loss of correction was more evident in standard SSTSF group at 6 and 12 months. More improvement in SCS was seen in group II. Therefore, use of intermediate pedicle screws at fracture level allowed reduction in the loss of kyphotic deformity correction and AVBH at a long term and improvement in indirect decompression of the spinal canal. Outcomes of standard SSTFS are in line with available literature data and benefits from intermediate screws placed at fracture level detected with clinical and imaging assessment are confirmed by reports based on in vitro studies or computeraided modeling. The study has limitations related to retrospective design with a small cohort of patients and a short follow-up period of one year. Greater cohorts of patients and a longer follow-up period can facilitate more accurate assessment of intermediate pedicle screws for SSTSF.

\section{CONCLUSION}

SSTSF added with intermediate pedicle screws has been shown to provide better maintenance of intraoperative kyphosis correction and vertebral height restoration of the affected vertebral body.
Indirect decompression of the spinal canal appeared to be more efficient with use of fracture level screws. Further prospective clinical trials can be required for comprehensive evaluation of the above technique.

Conflict of interests The article has been produced as part of the study on 'Development of technology of surgical reconstruction of unstable thoracolumbar fractures based on biomechanical modeling', governmental project of research and development at the Saratov State Medical University named after V.I. Razumovsky, Mininstry of Health of the Russian Federation. Registration No. AAAA-A18-118020290179-0.

\section{REFERENCES}

1. Joaquim A.F., De Almeida Bastos D.C., Jorge Torres H.H., Patel A.A. Thoracolumbar Injury Classification and Injury Severity Score System: A Literature Review of Its Safety. Global Spine J., 2016, vol. 6, no. 1, pp. 80-85. DOI: 10.1055/s-0035-1554775

2. Likhachev S.V., Zaretskov V.V., Shulga A.E., Gramma S.A., Shchanitsyn I.N., Bazhanov S.P., Zaretskov A.V., Donnik A.M. Povrezhdeniia perekhodnogo grudopoiasnichnogo otdela pozvonochnika: bibliometricheskii analiz angloiazychnoi literatury [Thoracolumbar junction injuries: a bibliometrical analysis of English-language literature]. Khirurgiia Pozvonochnika, 2018, vol. 15, no. 4, pp. 52-69. (in Russian) DOI:10.14531/ss2018.4.52-69

3. Gubin A.V., Prudnikova O.G., Burtsev A.V., Khomchenkov M.V., Kotel'nikov A.O. Drenirovanie posleoperatsionnykh ran v khirurgii pozvonochnika [Role of postoperative wound drains in spinal surgery]. Genij Ortopedii, 2017, vol. 23, no. 2, pp. $180-196$. (in Russian) DOI:10.18019/1028-4427-2017-23-2-180-186

4. Waqar M., Van-Popta D., Barone D.G., Bhojak M., Pillay R., Sarsam Z. Short versus long-segment posterior fixation in the treatment of thoracolumbar junction fractures: a comparison of outcomes. Br. J. Neurosurg., 2017, vol. 31, no. 1, pp. 54-57. DOI: 10.1080/0 2688697.2016.1206185 
5. Aono H., Ishii K., Tobimatsu H., Nagamoto Y., Takenaka S., Furuya M., Chiaki H., Iwasaki M. Temporary short-segment pedicle screw fixation for thoracolumbar burst fractures: comparative study with or without vertebroplasty. Spine J., 2017, vol. 17, no. 8, pp. 1113-1119. DOI: 10.1016/j.spinee.2017.03.022

6. Spiegl U.J., Devitt B.M., Kasivskiy I., Jarvers J.S., Josten C., Heyde C.E., Fakler H.M. Comparison of combined posterior and anterior spondylodesis versus hybrid stabilization in unstable burst fractures at the thoracolumbar spine in patients between 60 and 70 years of age. Arch. Orthop. Trauma Surg., 2018, vol. 138, no. 10, pp. 1407-1414. DOI: 10.1007/s00402-018-2993-y

7. Kolesov S.V., Kolbovskiy D.A., Shvets V.V., Rerikh V.V., Vishnevskiy A.V., Morozova N.S., Skorina I.V., Gorbatyuk D.S. Dvukhletnie rezultaty khirurgicheskogo lecheniia perelomov pozvonochnika s primeneniem uglerodnykh implantatov (multitsentrovoe issledovanie) [Two-year results of spinal fracture treatment using carbon implants (Multicenter study)]. Genij Ortopedii, 2019, vol. 25, no. 3, pp. 360-367. (in Russian) DOI: 10.18019/1028-4427-2019-25-3-360-367

8. Shul'ga A.E., Norkin I.A., Ninel' V.G., Puchin'yan D.M., Zaretskov V.V., Korshunova G.A., Ostrovskii V.V., Smol'kin A.A. Contemporary views on the pathogenesis of trauma of the spinal cord and peripheral nerve trunks. Neuroscience and Behavioral Physiology, 2015, vol. 45, no. 7, pp. 811-819. DOI: 10.1007/s11055-015-0148-y

9. Zaretskov V.V., Arsenievich V.B., Likhachev S.V., Shulga A.E., Stepukhovich S.V., Bogomolova N.V. Zastareloe povrezhdenie perekhodnogo grudopoiasnichnogo otdela pozvonochnika [Long-standing injury of the spine thoracolumbar junction]. Ortopediia, Travmatologiia i Vosstanovitelnaia Khirurgiia Detskogo Vozrasta, 2016, vol. 4, no. 2, pp. 61-66. (in Russian) DOI: 10.17816/ PTORS4261-66

10.Tomilov A.B., Kuznetsova N.L. Ortopedicheskaia korrektsiia posttravmaticheskikh deformatsii pozvonochnika [Orthopedic correction of posttraumatic spinal deformities]. Genij Ortopedii, 2012, no. 1, pp. 60-63. (in Russian)

11. Dudaev A.K., Khan I.Sh., Dupaeva N.M. Prichiny neudovletvoritelnykh anatomo-funktsionalnykh rezultatov lecheniia bolnykh s perelomami grudnogo i poiasnichnogo otdelov pozvonochnika [Reasons for unsatisfactory anatomic-and-functional results of treating patients with fractures of the thoracic and lumbar spine]. Khirurgiia Pozvonochnika, 2009, no. 2, pp. 17-24. (in Russian)

12.Wang H., Mo Z., Han J., Liu J., Li C., Zhou Y., Xiang L., Yang L. Extent and location of fixation affects the biomechanical stability of short- or long-segment pedicle screw technique with screwing of fractured vertebra for the treatment of thoracolumbar burst fractures: An observational study using finite element analysis. Medicine (Baltimore), 2018, vol. 97, no. 26, pp. e11244. DOI: 10.1097/MD.0000000000011244

13.Donnik A.M., Kirillova I.V., Kossovich L.Yu., Zaretskov V.V., Lykhachev S.V., Norkin I.A. Biomechanical modeling of reconstructive intervention on the thoracolumbar transition. AIP Conference Proceedings, 2018, vol. 1959, issue 1, id. 090002, pp. 90-102. DOI: $10.1063 / 1.5034741$

14.Vaccaro A.R., Oner C., Kepler C.K., Dvorak M., Schnake K., Bellabarba C., Reinhold M., Aarabi B., Kandziora F., Chapman J., Shanmuganathan R., Fehlings M., Vialle L.; AOSpine Spinal Cord Injury \& Trauma Knowledge Forum. AOSpine thoracolumbar spine injury classification system: fracture description, neurological status, and key modifiers. Spine (Phila. Pa. 1976), 2013, vol. 38, no. 23, pp. 2028-2037. DOI: 10.1097/BRS.0b013e3182a8a381

15.Spiegl U.J., Josten C., Devitt B.M., Heyde C.E. Incomplete burst fractures of the thoracolumbar spine: a review of literature. Eur. Spine J., 2017, vol. 26, no. 12, pp. 3187-3198. DOI: 10.1007/s00586-017-5126-3

16.Parker J.W., Lane J.R., Karaikovic E.E., Gaines R.W. Successful short-segment instrumentation and fusion for thoracolumbar spine fractures: a consecutive 41/2-year series. Spine (Phila. Pa. 1976), 2000, vol. 25, no. 9, pp. 1157-1170. DOI: 10.1097/00007632200005010-00018

17.Dobran M., Nasi D., Brunozzi D., Di Somma L., Gladi M., Iacoangeli M., Scerrati M. Treatment of unstable thoracolumbar junction fractures: short-segment pedicle fixation with inclusion of the fracture level versus long-segment instrumentation. Acta Neurochir. (Wien), 2016, vol. 158, no. 10, pp. 1883-1889. DOI: 10.1007/s00701-016-2907-0

18.Jindal N., Sankhala S.S., Bachhal V. The role of fusion in the management of burst fractures of the thoracolumbar spine treated by short segment pedicle screw fixation: a prospective randomized trial. J. Bone Joint Surg. Br., 2012, vol. 94, no. 8, pp. 1101-1106. DOI: $10.1302 / 0301-620 X .94 B 8.28311$

19.Tezeren G., Kuru I. Posterior fixation of thoracolumbar burst fracture: short-segment pedicle fixation versus long-segment instrumentation. J. Spinal Disord. Tech., 2005, vol. 18, no. 6, pp. 485-488. DOI: 10.1097/01.bsd.0000149874.61397.38

20.Afaunov A.A., Kuzmenkov A.V. Transpedikuliarnaia fiksatsiia pri povrezhdeniiakh grudnogo i poiasnichnogo otdelov pozvonochnika, soprovozhdaiushchikhsia travmaticheskim stenozom pozvonochnogo kanala [Transpedicular fixation for the injuries of the thoracic and lumbar spine accompanied by traumatic stenosis of the spinal canal]. Khirurgiia Pozvonochnika, 2011, no. 4, pp. 8-17. (in Russian)

21.Alanay A., Acaroglu E., Yazici M., Oznur A., Surat A. Short-segment pedicle instrumentation of thoracolumbar burst fractures: does transpedicular intracorporeal grafting prevent early failure? Spine (Phila. Pa. 1976), 2001, vol. 26, no. 2, pp. $213-217$. DOI: 10.1097/00007632-200101150-00017

22.Park S.H., Kim S.D., Moon B.J., Lee S.S., Lee J.K. Short segment percutaneous pedicle screw fixation after direct spinal canal decompression in thoracolumbar burst fractures: An alternative option. J. Clin. Neurosci., 2018, vol. 53, pp. 48-54. DOI: 10.1016/j. jocn.2018.04.039

23.Korovessis P., Baikousis A., Zacharatos S., Petsinis G., Koureas G., Iliopoulos P. Combined anterior plus posterior stabilization versus posterior short-segment instrumentation and fusion for mid-lumbar (L2-L4) burst fractures. Spine (Phila. Pa. 1976), 2006, vol. 31, no. 8, pp. 859-868. DOI: 10.1097/01.brs.0000209251.65417.16

24.Canbek U., Karapinar L., Imerci A., Akgün U., Kumbaraci M., Incesu M. Posterior fixation of thoracolumbar burst fractures: is it possible to protect one segment in the lumbar region? Eur. J. Orthop. Surg. Traumatol., 2014, vol. 24, no. 4, pp. 459-465. DOI: $10.1007 / \mathrm{s} 00590-013-1326-7$

25.Tian J.W., Wang L., Xia T., Liu C.Y., Zhao Q.H., Dong S.H. Posterior short-segmental fixation combined with intermediate screws vs conventional intersegmental fixation for monosegmental thoracolumbar fractures. Orthopedics, 2011, vol. 34, no. 8, pp. e389-e396. DOI: 10.3928/01477447-20110627-08 
26.Su Y., Wang X., Ren D., Liu Y., Liu S., Wang P. A finite element study on posterior short segment fixation combined with unilateral fixation using pedicle screws for stable thoracolumbar fracture. Medicine (Baltimore), 2018, vol. 97, no. 34, pp. e12046. DOI: 10.1097/MD.0000000000012046

27.Vissarionov S.V., Mushkin A.Iu., Belianchikov S.M., Kokushin D.N. Khirurgicheskoe lechenie mnozhestvennykh nestabilnykh neoslozhnennykh perelomov pozvonochnika u detei [Surgical treatment of multiple unstable non-complicated fractures of the spine in children]. Khirurgiia Pozvonochnika, 2010. № 3. s. 8-13. (in Russian)

28.Vissarionov S.V., Baindurashvili A.G., Mushkin A.Iu., Ulrikh E.V. Khirurgicheskoe lechenie vzryvnykh perelomov tel pozvonkov grudnogo i poiasnichnogo otdelov u detei [Surgical treatment of burst fractures of the thoracic and lumbar vertebral bodies in children]. Travmatologiia i Ortopediia Rossii, 2006, no. 1 (39), pp. 10-15. (in Russian)

29.Ye C., Luo Z., Yu X., Liu H., Zhang B., Dai M. Comparing the efficacy of short-segment pedicle screw instrumentation with and without intermediate screws for treating unstable thoracolumbar fractures. Medicine (Baltimore), 2017, vol. 96, no. 34, pp. e7893. DOI: 10.1097/MD.0000000000007893

30.Liu H., Wang H., Liu J., Li C., Zhou Y., Xiang L. Biomechanical comparison of posterior intermediate screw fixation techniques with hybrid monoaxial and polyaxial pedicle screws in the treatment of thoracolumbar burst fracture: a finite element study. J. Orthop. Surg. Res., 2019, vol. 14, no. 1, pp. 122. DOI: 10.1186/s13018-019-1149-2

31.Tong M.J., Tang Q., Wang C.G., Xiang G.H., Chen Q., Xu H.Z., Tian N.F. Efficacy of using intermediate screws in shortsegment fixation for thoracolumbar fractures: A meta-analysis of randomized controlled trials. World Neurosurg., 2018, vol. 110, pp. e271-e280. DOI: 10.1016/j.wneu.2017.10.157

Received: 01.04.2020

\section{Information about the authors:}

1. Sergey V. Likhachev, M.D., Ph.D., Saratov State Medical University named after V.I. Razumovsky, Saratov, Russian Federation, Email: likha4@mail.ru

2. Vladimir V. Zaretskov, M.D., Ph.D., Professor,

Saratov State Medical University named after V.I. Razumovsky, Saratov, Russian Federation

3. Vladislav B. Arsenievich, M.D., Ph.D.,

Saratov State Medical University named after V.I. Razumovsky, Saratov, Russian Federation

4. Vladimir V. Ostrovskij, M.D., Ph.D.,

Saratov State Medical University named after V.I. Razumovsky, Saratov, Russian Federation

5. Alexei E. Shulga, M.D., Ph.D.,

Saratov State Medical University named after V.I. Razumovsky, Saratov, Russian Federation

6. Alexander V. Zaretskov, M.D., Ph.D.,

Saratov State Medical University named after V.I. Razumovsky, Saratov, Russian Federation 